\title{
Erişkin kistik fibrozis: Olgu sunumu
}

\section{Adult cystic fibrosis: A case report}

\section{Eylem YILDIRIM, Yavuz Selim INTEPE, Bülent ÇiFTÇí}

Bozok Üniversitesi Tıp Fakültesi, Göğüs Hastalıkları Anabilim Dalı, Yozgat/TÜRKIYE

\begin{abstract}
öz
Kistik fibrozis (KF), kistik fibrozis transmembran regulator proteini (KFTR) genindeki mutasyonlar sonucu oluşan otozomal resesif ciddi bir hastalıktır. Klasik KF sık solunum yolu enfeksiyonları ve pankreas yetmezliği ile karakterize progresif bir bozukluktur ve çocukluk çağında tanı alır. Hastaların \%2'si infertilite, akut veya kronik pankreatit, sinüzit, bronşektazi ve nazal polip bulgularını içeren " non klasik" ya da "atipik" fenotipe sahiptir. Atipik KF semptomları tipik KF ile karşılaştırıldığında genellikle daha hafiftir ve erişkin yaşa kadar bulgu vermeyebilir. Otuz üç yaşında bronşektazi, infertilite ve sinüzit tanısı bulunan erkek hastayı atipik KF'in farklı organ sistemlerini değişen derecelerde etkileyen ve çok çeşitli tablolarla ortaya çıkan bir bozukluk olduğunu hatırlatmak ve tüm uzman hekimlerin pratiğinde akılda bulundurması gerektiğini vurgulamak amacıyla sunduk.
\end{abstract}

Anahtar kelimeler: atipik kistik fibrozis; bronşektazi; infertilite; sinüzit

\section{ABSTRACT}

Cystic fibrosis (CF) is a severe autosomal recessive disease that is caused by the defect of the cystic fibrosis transmembrane regulator gene (CFTR). Typical CF is a progressive disorder characterized by frequent respiratory infections and pancreatic insufficiency and is diagnosed in infancy or early childhood. In $2 \%$ of patients there is an "non-classic" or "atypical" phenotype which consists of infertility, acute or chronic pancreatitis, sinusitis, bronchectasia and nasal polyps. The symptoms associated with atypical CF are generally milder when compared to symptoms of typical CF and may not begin until adulthood. We reported a thirty-three years old male patient with bronchiectasis, infertility and sinusitis to mention that atypical CF could be a very diverse disorder affecting different organ systems to varying degrees and should always kept in mind in all specialties' practice.

Keywords: atypical cysticfibrosis; bronchiectasis; infertility; sinusitis

Sorumlu Yazara: Eylem Yıldııım, Bozok Üniversitesi Tıp Fakültesi, Göğüs Hastalıkları Anabilim Dalı, Yozgat/TÜRKiYE E-posta:yddreylemyildirim@gmail.com Recevied: 02.04.2017 accepted: 11.05.2017

Doi: $10.18663 /$ tjcl.303549 


\section{Giriş}

Kistik fibrozis (KF), kistik fibrozis transmembran regulator proteini (KFTR) genindeki mutasyon sonucu oluşan ve otozomal resesif kalıtım gösteren ölümcül bir hastalıktır [1]. Temel bozukluk ter ve tükürük bezleri, trakeabronşial ağaç, kalın barsak ve pankreasa ait ekzokrin glandlarda anormal sekresyonların oluşumudur. Sıklığının canlı doğumlarda 1/2000-1/3500 olduğu ve beyaz ırkta özellikle Kuzey Avrupa ülkelerinde daha sık olduğu bildirilmektedir [2]. KF kliniğin ağırlığı, KFTR gen mutasyonunun tipine göre değişir. Ekzokrin bezlerin koyu yapışkan mukus salgılamaları nedeni ile olguların çoğu tekrarlayan veya düzelmeyen akciğer enfeksiyonu, kronik öksürük, tekrarlayan bronşit atakları ve malnutrisyon tabloları ile çocukluk döneminde tanı almaktadır. KF'li hastaların bazılarında KFTR proteini kısmen de olsa görev yapabildiğinden, klinikleri hafiftir. Akciğer tutulumları tipik KF'e göre daha geç başlangıçlı olan, daha çok kronik sinüzit, tekrarlayan pankreatit, fokal biliyer siroz, kolestaz, infertilite veya sıcak intoleransı nedeniyle başvuran bu hastalara" non klasik" ya da "atipik" KF denir [3]. Basit ve ucuz bir yöntem olan ter testi tanıda altın standart yöntemdir. Bazı atipik KF hastalarında ter testi normal veya sınırda saptandığında genetik mutasyon araştırılması önerilmektedir. Daha önce bronşektazi tanısı ile takip ve tedavi edilen hastamızda altta yatan hastalık olarak KF tanısı koyduk. Özellikle genç yaşta olan ve bronşektaziye akciğer dışı patolojilerin eşlik ettiği hastalarda KF'in ayırıcı tanıda akılda bulundurulması gerektiğini, şüphelenildiği taktirde tanıya ulaşmada ter testi gibi basit ve ucuz bir yöntemin sıklıkla yeterli olduğunu vurgulamak amacıyla olgumuzu sunduk.

\section{Olgu}

Otuz üç yaşında, evli erkek hasta öksürük, yeşil renkli balgam çıkarma, nefes darlığı ve ateş yüksekliği yakınmaları ile başvurdu ve enfekte bronşektazi saptanarak servisimize yatırıldı. Çocukluğundan beri sık enfeksiyon geçirme öyküsü bulunan hasta üç yıldır bronşektazi tanısı ile izlenmekteydi. Son bir yıldır kronik solunum yetmezliği gelişmesi nedeni ile uzun süreli oksijen tedavisi başlanmıştı. Son üç ayda üç kez hastaneye yatırılma öyküsü vardı. Sigara hiç kullanmamıştı. Pasif sigara dumanı maruziyeti ile biomass dumanı maruziyeti yoktu. Dört yıldır evli olan hastanın çocuğu bulunmamaktaydı. Yapılan tetkiklerinde azospermi saptanmıştı. Soy geçmişinde özellik olmayan hastanın anne ve babası kuzenlerdi. Yatışında ateş: $38.0 \mathrm{C}$, tansiyon: 100/60 mmHg, beden kitle indeksi: 23 kg/m2 idi. Fizik muayenede dispneik ve soluk görünümdeydi. Ellerde çomak parmak izlendi. Solunum sistemi muayenesinde her iki akciğerde orta ve alt alanlarda inspiratuvar raller mevcuttu. Yatışında eritrosit sedimentasyon hızı 38 mm/h idi. Nazal kanülle 3 litre/dakika ok- sijen inhalasyonu alıyorken arteryel kan gazında pH: 7,36, pCO2: 46.9 mmHg, pO2: 71,5mmHg, HCO3: 26.3, SatürasyonO2: \%92,5 saptandı. Son 1 ay içinde hastanede yatış öyküsü ve balgam kültüründe Pseudomonas aeruginosa üreme öyküsü olan hastaya enfeksiyon hastalıkları tarafından ampirik tedavi olarak meropenem 1 gr 3x1 IV başlandı. Antibiyotik tedavi öncesinde alınan balgam örneği kültüründe Pseudomonas aeruginosa üredi. Çekilen yüksek rezolüsyonlu bilgisayarlı tomografi (YRBT)'de her iki üst lobda, sağda orta lobda ve solda lingulada yaygın olan kısmen kistik görünümde bronşiektazi alanları (Resim1), paranazal sinüs bilgisayarlı tomografide ise bilateral maksiller sinüzit izlendi. Allerjik bronkopulmoner aspergillozis (ABPA) ile ayırıcı tanısı için yapılan deri prick testinde aspergillus negatifti. Serum Aspergillus spesifik lgE negatif, total lgE: $500 \mathrm{lU} / \mathrm{ml}$ tespit edildi. Önceden bilinen bir pnömoni geçirme öyküsü olmaması, sinüzit bulguları ve infertilite (azospermi) bulguları nedeniyle hastada bronşektazi etiyolojide kistik fibrozis araştırıldı. Pilokarbin elektroforez yöntemiyle terde klor konsantrasyonu $85 \mathrm{mEq} / \mathrm{lt}$ (0-40 mEq/lt normal; 40-60 mEq/lt şüpheli; 60 mEq/lt ve üzerinde yüksek) ölçüldü. Hastaya kistik fibrozis tanısı konuldu. Kistik fibrozis, bronşektazi ve kronik solunum yetmezliği tanıları olan hastaya enfeksiyon tedavisi tamamlandıktan sonra konsey kararı ile transplantasyon merkezine başvurusu önerildi.

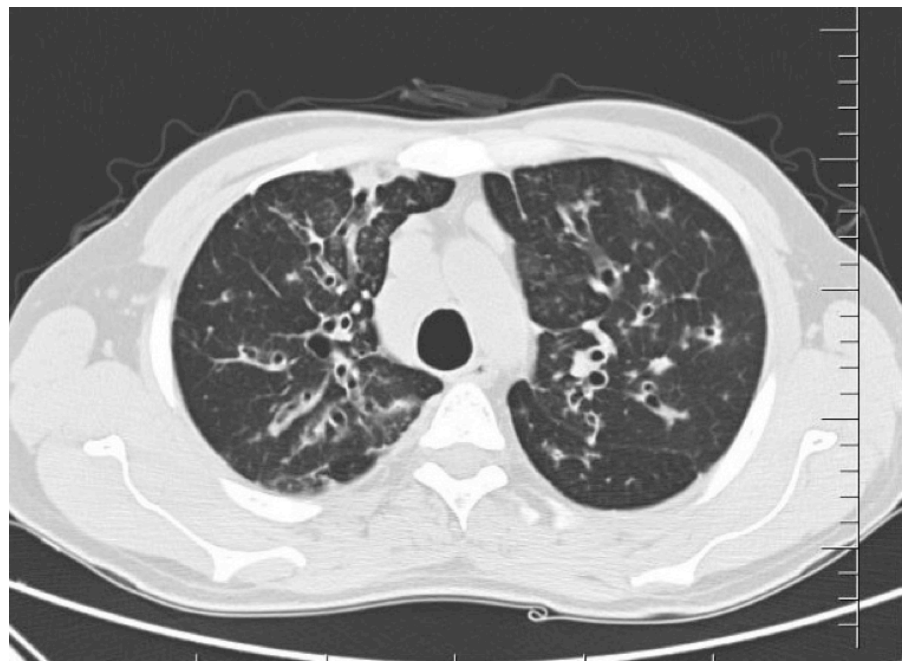

Resim 1: Olgunun YRBT'de üst lob kesitinde bilateral bronşektazi alanları

\section{Tartışma}

KF, yaklaşık 1/25 taşıyıcı sıklığı ve 1/2000-3500 canlı doğum insidansı ile, beyaz ırkta otozomal resesif geçiş gösteren en yaygın hastalıktır [4]. Her etnik grupta görülebildiği ve hastalık insidansının popülasyonlar arasında farklılıklar gösterdiği bildirilse de bu oranlar Avrupa ülkelerinin ve Amerika Birleşik Devletleri $(A B D)$ 'nin verileri ile belirlenmiştir. Ülkemizdeki KF oranı ise bilinmemekle birlikte yaygın kanı nadir bir hastalık olduğu yönündedir. Ancak ülkemizde akraba evliliğinin görül- 
me sıklığı Türkiye Nüfus ve Sağlık Araştırması 2008 verilerine göre \%24.1 gibi oldukça yüksek bir orandır [5]. Bu durumun otozomal resesif geçişli bir hastalığın insidansını arttırdığını düşünmek yanlış değildir. Ülkemizde yapılan KF çalışmalarında Erdem ve ark. KF tanılı 41 çocuk hastayı değerlendirdiklerinde anne babanın akraba evliliği oranını \%61.1, Uçar ve ark. ise 78 KF tanılı hastada anne babanın akraba evliliği oranını \%52.6 saptamıştır [6,7]. KF'in Ocak 2015'ten itibaren yenidoğan tarama testlerine dahil edilmesi ile yakın zamanda toplumumuzdaki insidansının da belirleneceği beklenmektedir. KFTR genindeki en sık mutasyon tipi dünya genelinde \%66 sıklıkla rastlanan deltaF508 mutasyonudur. Bu oran Kuzey Avrupa'da \%87 iken, Asya'da \%28'dir [8]. Ancak deltaF508 dışında KFTR geninin yaklaşık 2000 mutasyonu daha olduğu belirlenmiştir [9]. KFTR genindeki değişik mutasyonlar hastalığın farklı tabIolarla ortaya çıkmasına sebep olurlar. Ülkemizde de KF hastalarının gen analizleri ile ilgili çalışmalar mevcuttur. Öztürk ve ark'nın Adana ilindeki KF tanılı 63 hastada yaptığı çalışmada deltaF508 mutasyon oranı \%11.9 bulunmuştur[10]. Karakoç ve ark.'nın yanı sıra Onay ve ark.'nın yaptığı çalışmalarda da deltaF508 mutasyonu en sık rastlanan mutasyon olmuş ancak oranları sırasıyla \%17 ve \%18.6 olarak saptanmıştır $[11,12]$. Çalışmaların çoğunda deltaF508 mutasyon oranı Avrupa ortalamalarının çok altında görülmekle beraber bazı çalışmalarda benzer oranlar da saptanmıştır [6]. Bu durumda etkili faktörün bölgesel farklılıklar olduğu düşünülmektedir. Kılınç ve ark.'nın 83 KF hastasında KFTR mutasyonlarını belirlemek amacıyla yaptığı çalışmada ise popülasyonda 36 değişik KFTR mutasyonu saptanmış ve bu sonuçlarla Türk popülasyonunun bugüne kadar bildirilenlerin içinde en yüksek genetik heterojeniteye sahip olduğu belirtilmiştir[13]. Bu çalışmalarda da görüldüğü gibi nadir mutasyonların toplumumuzda saptanması nedeniyle ülkemizde atipik klinik tablolarla başvuran KF hastalarının sanılandan daha sık olduğunu düşünmekteyiz.

KF'te de KFTR fonksiyonunun bozulması ile sodyumun emilimi artar, klor absorpsiyonu bozulur. Bu iyon dengesizliği hava yolu yüzeyinde dehidratasyon oluşturduğu gibi tuz fazlalığına da yol açar. Sonuçta bronşiyal sistemde siliyer fonksiyonlarda bozulma, mukus stazı ve antibakteriyel proteinler olan beta defensin, lizozim, laktoferrin fonksiyonlarında azalma ile hava yollarında kronik bakteriyel enfeksiyonlara yatkınlık gelişir [14]. KF'de gelişen bu kronik bakteriyel enfeksiyonlar bronş ve akciğer dokusunda destrüksiyon ile bronşektazi oluşumuna neden olur [15]. Multipl organ tutulumu ile prezente olan ve çocukluk çağında tanı alan klasik KF'in aksine erişkin tipi çoğunlukla atipik kliniktedir. Bu hastaların çoğunun pankreas fonksiyonları yeterlidir ve malabsorbsiyon bulguları yoktur. Genellikle akciğer tutulumları tipik KF'li hastalara göre daha hafif ve geç başlangıçlı olur ve en çok etkilenen organa göre tekrarlayan sinüzit, idiopatik bronşektazi ya da infertilite nedeniyle incelenmekteyken tanı alırlar [16]. Olgumuzda büyümegelişme geriliği izlenmemekteydi ve yaklaşık 30 yaşında ilk kez bronşektazi tanısı almıştı. Bronşektazi tanısı alması öncesinde sinüzit ve infertilite nedeni ile bir çok kez kulak-burun-boğaz ve üroloji kliniklerinde tetkik edilmiş ancak KF araştırılmamıştı. Geç başlangıçlı olması, malnütrisyon bulunmaması, sinuzit, infertilite ve bronşektazi kliniği ile olgumuz atipik KF ile uyumludur. KF'in atipik varyantlarının sıklıkla erişkin yaşta görülmesi ve bronşektazi gelişiminden çok daha önce olan sinüzit, infertilite gibi bulgularla seyredebilmesi nedeniyle hastaların başvuruları göğüs hastalıkları dışı branşlara olabilmektedir. Ülkemizde KFTR'deki genetik heterojenitenin çalışmalarda fazla olduğunun gösterilmesi ve akraba evliliğinin yaygın olması göz önüne alındığında KF'in atipik klinik tablolarının çok daha fazla olduğunu ve tanıda çoğunlukla atlandığını düşünmekteyiz. Sonuç olarak özellikle genç olan ve infertilite, sinüzit gibi başka organ disfonksiyonlarının da eşlik ettiği bronşektazi hastalarında akraba evliliği sorgulanmalı ve atipik KF tanısı akılda bulundurulmalıdır. Bu hastalara çok ucuz ve pratik bir tanı testi olan ter testi uygulanmalı, ter testi ile sonuç alınamıyorsa genetik mutasyon araştırması ile tanı kesinleştirilmelidir. KF'in sadece pediatri ve göğüs hastalıkları branşlarını ilgilendiren bir hastalık olmadığı bilinmeli ve özellikle ekzokrin bezlerle ilgilenen diğer branşlarda da farkındalığı arttırılmalıdır.

\section{Çıkar çatışması / finansal destek beyanı}

Bu yazıdaki hiçbir yazarın herhangi bir çıkar çatışması yoktur. Yazının herhangi bir finansal desteği yoktur

\section{Kaynaklar}

1. Parad RB, Comeau AM. Newborn screening for cystic fibrosis. Pediatr Ann 2003; 32: 528-35.

2. Andersen DH, Hodges RH. Celiacsyndrome; genetics of cysticfibrosis of thepancreas, with a consideration of etiology. Am J Dis Child 1946; 72: 62-80

3. Boyle MP. Non classic cystic fibrosis and CFTR-related diseases. Curr Opin in Pulm Med 2003; 9: 498-503

4. Lewis PA. The epidemiyology of cystic fibrosis. In: Hodson ME, Gedder DM, eds. Cysticfibrosis. 1st ed. London: Chapman\& Halil Medical 1995; 1-13.

5. Türkiye Nüfus ve Sağlık Araştırması, 2008 İleri Analiz Çalışması. www.hips.hacettepe.edu.tr/turkiyede_dogurganlik_ureme_ sagligi_yaslilik_160910.pdf 
6. Erdem M, Zorlu P, Acar M, Şenel S. Kistik Fibrozisli Hastaların Demografik ve Klinik Özelliklerinin Değerlendirilmesi Turkish J Pediatr Dis 2013; 3: 134-37

7. Uçar Ş, Zorlu P, Polar E. Kistik Fibrozisli Bebeklerin Klinik ve Laboratuvar Özellikleri. Turkiye Klinikleri J Med Sci 2014; 34: 385-95

8. Cystic Fibrosis Mutation Database. http://www.genet.sickkids. on.ca/cftr/ resource/Table1.html erişim tarihi 16.10.2016

9. Cystic Fibrosis Mutation Database. http://www.genet.sickkids. on.ca/cftr/StatisticsPage. html erişim tarihi 16.10.2016

10. Ozturk OG, Kibar F, Karacor EDZ, Cetiner S, Sahin G, Yaman A. Adana İlinde CFTR Gen Mutasyonlarının Değerlendirilmesi. Cukurova Med J 2013; 38: 202-8

11. Karakoç F, Karadağ B, Erdoğan T, Kut A, Dağlı E. Kistik fibrozisli hastaların klinik özellikleri ve tedavi yaklaşımları. Turk Pediatr Ars 2002; 37: 19-24.
12. Onay T, Topaloglu O, Zielenski J et al. Analysis of the CFTR gene in Turkish Cystic fibrosis patients. Identification of three novel mutations (3172 delAC,P10113L and M110281). Hum Genet 1998; 102: 224-30.

13. Kilinç MO, Ninis VN, Dağli E et al. Highest heterogenity for cystic fibrosis: 36 mutations account for $75 \%$ of all CF chromosomes in Turkish patients. Am J Med Genet 2002; 113: 250-57.

14. Heijerman $\mathrm{H}$. Infection and inflammation in cystic fibrosis: A short review. J Cyst Fibros 2005; 4: 3-5.

15. Bonfield TL, Konstan MW, Berger M. Altered respiratory epithelial cell cytokine production in cystic fibrosis. J Allergy Clin Immunol 1999; 104: 72-78

16. Hodso nand Geddes' Cystic Fibrosis, Fourth Edition editör: Andrew Bush, Diana Bilton, Margaret Hodson p:149 